\title{
EXPRESSION OF AGGREGATIVE ADHERENCE TO HELA CELLS BY ESCHERICHIA COLI STRAINS ISOLATED FROM SICK HORSES
}

\author{
Ana Maria Alvim Liberatore ${ }^{1,2,3}$; Sandra Kimie Tomita ${ }^{1}$; Mônica Aparecida Midolli Vieira ${ }^{1}$; Cyro Toti Jr. ${ }^{2}$; \\ João Heckmaier²; Tânia Aparecida Tardelli Gomes ${ }^{1 *}$ \\ ${ }^{1}$ Universidade Federal de São Paulo, Escola Paulista de Medicina ${ }^{1}$, São Paulo, SP, Brazil; ${ }^{2}$ Jockey Club de São Paulo, São Paulo, \\ S P, Brazil; ${ }^{3}$ Present affiliation: Laboratório Clínico-Experimental de Gastroenterologia Pediátrica, São Paulo, SP
}

Submitted: February 24, 2006; Returned to authors for corrections: September 04, 2006; Approved: January 18, 2007

\begin{abstract}
The virulence attributes of 56 Escherichia coli strains isolated from sick horses (secretions of uterine cervices; gastrointestinal and lung fragments of necropsy; diarrheic feces, and tracheal washings) was examined by determining their adherence pattern to HeLa cells and searching for the presence of virulence genes of the various $E$. coli pathotypes. Two non-adherent strains presented astA, which encodes the enteroaggregative $E$. coli heat-stable toxin. Twenty-seven strains (48.2\%) adhered to HeLa cells, 21 (77.8\%) of which presented the aggregative adherence pattern (AA) that characterize the Enteroaggregative $E$. coli pathotype (EAEC). Nine of the strains presenting AA were isolated from secretions of uterine cervix, including one carrying virulence genes of the EAEC pathotype ( $\operatorname{aggR}$, aap, irp2, and pic). This is the first description of the AA phenotype amongst $E$. coli strains from sick horses. Such strains should be further evaluated regarding their potential role in the pathogenesis of diverse equine diseases and as reservoirs of human infections.
\end{abstract}

Key words: horse, Escherichia coli, aggregative adherence, virulence

\section{INTRODUCTION}

Although commensal Escherichia coli inhabits the intestinal lumen of humans and animals, certain $E$. coli strains carrying specific combinations of virulence genes may cause diarrhea, urinary tract infections or sepsis/ meningitis (22,32). According with their set of virulence genes and the signs and symptoms generated in the host, diarrheagenic $E$. coli strains are classified in distinct pathotypes named enteropathogenic E. coli (EPEC), enteroinvasive E. coli (EIEC), enterotoxigenic E. coli (ETEC), Shiga toxin-producing $E$. coli (STEC) or enterohemorrhagic $E$. coli (EHEC), diffuselly adherent E. coli (DAEC), and enteroaggregative E. coli (EAEC) (28). In addition, E. coli strains causing human extra-intestinal infections are collectively known as Extra-intestinal E. coli (ExPEC) (32).

Colonization is a fundamental step in the establishment of most bacterial diseases and depends on the ability of bacteria to adhere to host surfaces. Adhesiveness can be examined in HeLa and HEp- 2 cell lines in vitro, where E. coli strains may present at least 3 distinct adherence patterns: localized (LA), aggregative (AA), and diffuse (DA) adherence (28). These patterns distinguish strains belonging to the EPEC, EAEC and DAEC pathotypes, respectively. Furthermore, some E. coli strains have been reported to express a LA-like (LAL) pattern of adherence or to present a non-characteristic (NC) pattern with few bacteria attaching to the cells surfaces $(13,22)$.

In various animal species, $E$. coli strains sharing one or more characteristics with human pathogenic $E$. coli have been reported $(3,5,6,16,25,27,30)$. In horses, $E$. coli is one of the most common organisms in feces and blood of septic foals $(19,20,23)$ and is frequently detected in samples from endometritis and other important equine diseases $(17,18,20,26,31)$. Holland et al. (19) showed that $E$. coli strains from foal diarrheic feces harbored the stxl and stx2 genes (associated with the STEC/EHEC

*Corresponding Author. Mailing address: Departamento de Microbiologia, Imunologia e Parasitologia, Universidade Federal de São Paulo, Rua Botucatu 862, $3^{\circ}$ andar, CEP 04023-062, São Paulo, SP, Brazil. Tel.: (11) 5576-4537 ou (11) 5572-4711. E-mail: tatgomes@ecb.epm.br 
pathotypes) and eae, encoding the adhesive protein intimin (associated with both EPEC and STEC/EHEC). These findings, in addition to the demonstration of a characteristic ultrastructural damage to the brush border of equine epithelial cultured cells by an EPEC strain isolated from a diarrheic child (1), suggest that certain $E$. coli strains may be potential equine pathogens. However, little is known about their potential virulence attributes. In the present study we sought to examine the virulence potential of a collection of $E$. coli strains detected among various clinical samples from sick adult horses.

\section{MATERIALS AND METHODS}

\section{Origin of the strains studied}

Fifty-six strains, previously isolated and identified as E. coli according to Ewing (12), were selected randomly (one strain per sample) from a collection of $E$. coli strains detected among various clinical samples from sick adult horses infected by one single bacterial type (monobacterial infections) in the Microbiology Laboratory of Veterinarian Hospital of São Paulo Jockey Club (JCSP) in São Paulo city, Brazil. Fifteen strains, derived from sick mares of breeding farms, were formerly collected with swabs from uterine cervices secretions. Fragments of gastrointestinal tract (23 strains) and lungs ( 2 strains) were obtained from horses that died of diverse diseases. The remaining strains were isolated from clinical specimens from Thoroughbred ill horses and comprised feces (13 strains) from diarrheic horses and tracheal washings ( 3 strains) from horses with pneumonia.

\section{Determination of the pattern of adherence}

Adherence assays were performed in HeLa cells using the 3 $\mathrm{h}$ and $6 \mathrm{~h}$ assays (8). HeLa cells at $60 \%$ confluence were cultivated in 24-well tissue culture plates containing Minimal Essential Media (MEM) supplemented with 5\% of fetal calf serum. After two washes with PBS, $1.0 \mathrm{ml}$ of fresh media (MEM supplemented with $2 \%$ D-mannose) was dispensed on the cell monolayers. $E$. coli strains were grown overnight in Luria broth without shaking, and diluted 1:50 in the media contained in the microplates. After an incubation period of $3 \mathrm{~h}$ at $37^{\circ} \mathrm{C}$, monolayers were washed 10 times with PBS, fresh media was added to the wells, and an additional incubation period of $3 \mathrm{~h}$ proceeded ( $6 \mathrm{~h}$ assay). After 5 washes with PBS, the preparations were fixed with methanol, stained with May Grünwald-Giemsa, and examined blindly by light microscopy. Strains were considered adherent when more than $10 \%$ of cells per field presented bacteria (8). Laboratory $E$. coli strain HB101 was used as a non-adherent control while strains E2348/69 (28), JPN15 (28), C1845 (4), and 0431-4 (13) were used as controls of LA, LAL, DA, and AA, respectively.

\section{Search for virulence genes of diarrheagenic $E$. coli}

All $E$. coli strains were submitted to colony hybridization assays as previously described (36), using cloned or amplified genetic probe sequences for ETEC (LT-I, ST-Ih, and ST-Ip probes), EIEC (invasiveness plasmid probe), EPEC (eae, $b f p A$, and EAF probes), STEC/EHEC (stx and eae probes), EAEC (EAEC plasmid sequence), DAEC (daaC probe), and ExPEC ( $\alpha$-hemolysin probe) as well as for Cytolethal distending toxin ( $c d t$ probe), Cytotoxic necrotizing factor (cnf probe) and Enteroaggregative E. coli heat-stable enterotoxin 1 (EAST1) (astA probe).

To further characterize the $E$. coli strains that expressed AA in HeLa cells identified in this study, the presence of putative EAEC virulence genes was tested by PCR amplifications. The primers and conditions used were described previously (10). DNA extracts of prototype strains 042 (aafC, aggR, aap, shf, irp2, pet, and pic probes) and 17-2 (aggC probes) were used as positive controls.

\section{RESULTS}

Among the 56 strains tested, 27 (48.2\%) adhered to HeLa cells; $21(77.8 \%)$ of these 27 strains presented AA (AA+) and 6 $(22.2 \%)$, presented a non-characteristic pattern $(\mathrm{NC}+)$. Table 1 presents the frequency of adherent strains among the different clinical samples analyzed as well as their adherence patterns and distribution. Adherent strains were most frequently observed among E. coli strains isolated from secretions of uterine cervix $(60.0 \%)$ and gastrointestinal tract fragments $(56.5 \%)$, and were also detected in lungs $(50.0 \%)$ and feces (30.8\%). Most of the $21 \mathrm{AA}+$ strains were isolated from secretions of uterine cervix ( 9 strains, $42.8 \%$ ) and gastrointestinal tract necropsy fragments ( 8 strains, $38.1 \%$ ) while the $\mathrm{NC}+$ strains were most frequent in gastrointestinal necropsy fragments $(83.3 \%)$ (Table 1).

None of the strains carried $c d t$, cnf or the virulence DNA sequences associated with EPEC, STEC/EHEC, EIEC, ETEC, DAEC or ExPEC. Two non-adherent strains (from feces) reacted with astA.

The EAEC putative virulence genes described so far are located on a high molecular weight plasmid and comprise the agg and aaf operons (involved in the biogenesis of aggregative adherence fimbriae) $(2,28), \operatorname{agg} R$ (encoding the transcriptional activator AggR) (29), aap (formerly aspU, encoding dispersin) (34), shf (encoding a cryptic secreted protein, Shf) (9), and pet (encoding the Plasmid encoded toxin, Pet) (11). Chromosomal virulence genes have also been described in some EAEC strains, which comprise pic, encoding a Protein involved in colonization (Pic), and irp2, encoding the iron-repressible high-molecularweight protein 2 (Irp2) involved in Yersiniabactin expression (9). Only 5 of the $21 \mathrm{AA}+$ strains carried any of the genes searched for: one AA+ strain (from uterine cervix) reacted with the EAEC probe and four strains (one from uterine cervix and 3 from gastrointestinal fragments) carried irp2. The strain from uterine cervix that had the EAEC probe sequence also carried aggR, aap, pic, and irp2. 
Table 1. Adherence properties in HeLa cells of 56 Escherichia coli strains isolated from various equine clinical samples.

\begin{tabular}{lccc}
\hline Clinical samples & $\begin{array}{c}\mathrm{N}^{\circ} \text { of strains } \\
\text { tested }\end{array}$ & $\begin{array}{c}\mathrm{N}^{\mathrm{o}} \% \text { of } \\
\text { adherent strains }\end{array}$ & $\begin{array}{c}\text { Adherence pattern } \\
\mathrm{N}^{\circ} / \%^{\mathrm{b}}\end{array}$ \\
\hline Gastrointestinal & 23 & $13(56.5)$ & $\mathrm{AA} 8 / 38.1^{\mathrm{c}}$ \\
Tract (necropsy) & & & $\mathrm{NC} 5 / 83.3$ \\
Uterine cervix & 15 & $9(60.0)$ & $\mathrm{AA} 9 / 42.8^{\mathrm{cd}}$ \\
Feces & 13 & $4(30.8)$ & $\mathrm{AA} 3 / 14.3$ \\
& & & $\mathrm{NC} 1 / 16.7$ \\
Tracheal washing & 3 & 0 & - \\
Lungs (necropsy) & 2 & $1(50.0)$ & $\mathrm{AA} 1 / 4.8$ \\
\hline Total & 56 & $27(48.2)$ & $\mathrm{AA} 21 / 77.8$ \\
& & & $\mathrm{NC} 6 / 22.2$ \\
\hline
\end{tabular}

${ }^{a} \mathrm{AA}$, aggregative adherence; $\mathrm{NC}$, non-characteristic adherence; ${ }^{\mathrm{b}}$ Number of adherent strains and \% of total AA $(n=21)$ and $\mathrm{NC}(\mathrm{n}=6)$ adherent strains; ${ }^{\mathrm{c}}$ Three gastrointestinal and one uterine cervix strains carried $\operatorname{irp} 2 ;{ }^{\mathrm{d}}$ One strain reacted with the EAEC, pic, aap, aggR, and irp2 probe sequences.

(22). Recently, Kaper et al. (22) suggested that the term "typical EAEC" should be used for strains carrying $a g g R$ and a group of regulated genes, and "atypical EAEC" for the AA+ strains lacking these genes. According to this proposal, most of the AA+ strains found in the equine specimens should be regarded as atypical EAEC. However, although most authors consider only typical EAEC as pathogens, there are reports on outbreaks of diarrheal infections $(7,21)$ caused by atypical EAEC (EAEC probe negative strains). As discussed earlier, although only one strain was identified as typical EAEC, atypical EAEC strains were also obtained from animals with no other known pathogens (monobacterial infections), which were associated with clear clinical symptoms of infection, and responded very well to antibiotic therapy. Therefore, we considered these strains as potential pathogens. However, since many of these strains were isolated from extra-intestinal specimens (and not from diarrheic feces) it might not be appropriate to designate them as "enteroaggregative" E. coli.

$\mathrm{AA}+E$. coli has been previously found in feces

\section{DISCUSSION}

E. coli is one of the most commonly isolated organisms from tissues and blood of septic foals but their virulence potential is fairly unknown. Therefore, the present study was conducted to elucidate the nature of the virulence determinants encoded by E. coli strains isolated from various clinical samples of sick equines using an approach already used by our group in studies of infant diarrhea (36). None of the gene sequences tested, which were designed to detect 5 of the 6 human diarrheagenic E. coli pathotypes (ETEC, EIEC, EPEC, STEC/ EHEC, and DAEC) were found among the strains tested. Two non-adherent $E$. coli strains (from feces) reacted with $a s t A$, but as many $E$. coli isolates from other diarrheagenic pathotypes as well as commensal strains were shown to carry astA, this finding should not be emphasized until the role this toxin plays in diarrheal diseases be confirmed $(24,33)$.

Among the 56 E. coli tested, we found 21 strains expressing the AA pattern. Most AA+ strains were isolated from secretions of uterine cervix (42.8\%) and from Gastrointestinal fragments (38.1\%). One of these AA+ strain (from uterine cervix) probably carried the EAEC plasmid, as indicated by the fact that it reacted with the EAEC probe and carried the aggR, aap, irp2, and pic genes. Thus, of those AA+E. coli, only one was shown to harbor all those factors generally associated with clinically significant human EAEC. EAEC strains are considered human emerging diarrheagenic pathogens, but it is commonly accepted that it is a heterogeneous group comprising pathogenic and non-pathogenic strains that share the common AA phenotype of monkeys and dogs $(6,27)$, but to our knowledge, the present study is the first description of such strains in horses. Moreover, as far as we know, the presence of AA+E. coli strains in host regions outside the intestinal tract has been reported only in human urinary tract infections $(14,15)$. Interestingly, although AA+ strains have been detected in feces and necropsy intestinal fragments, in the present study they were isolated mainly from secretions of uterine cervices and from specimens collected from intestines (feces and necropsy fragments) and lung fragments. One explanation for finding EAEC in extraintestinal sites could be that in horses, fecal contamination can spread to unusual sites, possibly due to the contiguity of the cervix to the anus and the easy fecal contact with the respiratory tract by their housing characteristics. Thus, since this survey used a strain collection that is likely to hold pathogenic, nonpathogenic commensals and possible cross-contaminating isolates, the significance of this finding is unclear. Recently, Uber et al. (35) characterized a collection of EAEC strains of human and animal specimens in order to investigate a possible role of animals as reservoir for EAEC human infections. In their work they included some of the EAEC strains used in the present study. Their results demonstrated that EAEC strains of human and animal sources are serologically and genotypically distinct, suggesting that the animal strains may not represent potential reservoirs for human infections. However, those data may not be conclusive due to the small number of equine strains studied. Besides, due to the proximity between human and animals, a possible contamination of people who work with infected animals cannot be dismissed. Further studies analyzing a larger 
collection of strains from sick and healthy horses (matched controls) should be performed to better assess the association of $\mathrm{AA}+$ E. coli strains with different equine diseases and as a reservoir of human infections.

\section{ACKNOWLEDGEMENTS}

This work was supported by FINEP/MCT/PRONEX grant (41.96.0881.00).

\section{RESUMO}

\section{Expressão de aderência agregativa em células HeLa por amostras de $E$. coli isoladas de eqüinos doentes}

Características de virulência de 56 amostras de Escherichia coli isoladas de eqüinos doentes (secreção de colo uterino, fragmentos de necrópsia do trato gastrointestinal e de pulmões, fezes diarréicas e lavado traqueal) foram examinadas para determinar o padrão de aderência em células HeLa e pesquisar a presença de genes de virulência de vários patotipos de $E$. coli. Duas amostras não aderentes apresentaram astA, gene que codifica a toxina termo-estável de $E$. coli enteroagregativa. Das vinte e sete amostras $(48,2 \%)$ que aderiram a células HeLa, 21 (77,8\%) apresentaram o padrão de aderência agregativa (AA) que caracteriza o patotipo de E. coli Enteroagregativa (EAEC). Nove destas amostras que apresentaram AA foram isoladas de secreção de colo uterino, incluindo uma que apresentava genes de virulência de patotipos de EAEC (aggR, aap, irp2 e pic). Esta é a primeira descrição do fenótipo AA em amostras de cavalos doentes. Estas amostras deverão ser melhor avaliadas em relação a sua potencial função na patogênese de diferentes doenças eqüinas, bem como à possibilidade destes animais representarem um reservatório de infecções humanas causadas por esta bactéria.

Palavras chave: eqüino, Escherichia coli, adesão agregativa, virulência

\section{REFERENCES}

1. Batt, R.M.; Embaye, H.; Hunt, J.; Hart, A.C. (1989). Ultrastructural damage to equine intestinal epithelium induced by enteropathogenic Escherichia coli. Equine Vet. J. 21, 373-375.

2. Bernier, C.; Gounon, P.; Le Bouguénec, C. (2002). Identification of an aggregative adhesion fimbria (AAF) type III-encoding operon in enteroaggregative Escherichia coli as a sensitive probe for detecting the AAF-encoding operon family. Infect. Immun., 70, 43024311.

3. Beutin, L. (1999). Escherichia coli as a pathogen in dogs and cats. Vet. Res., 30, 285-298.

4. Bilge, S.S.; Clausen, C.R.; Lau, W.; Moseley, S.L. (1989). Molecular characterization of a fimbrial adhesin, F1845, mediating diffuse adherence of diarrhea-associated Escherichia coli to HEp-2 cell. J. Bacteriol., 171, 4281-4289.
5. Blanco, M.; Blanco, J.E.; Ramos, J. (1993). Enterotoxigenic, verotoxigenic and necrotoxigenic Escherichia coli isolated from cattle in Spain. Amer. J. Vet. Res., 54, 1446-1451.

6. Carvalho, V.M.; Gyles, C.L.; Ziebell, K.; Ribeiro, M.A.; Catão-Dias, J.L.; Sinhorini, L.L.; Otman, J.; Keller, R.; Trabulsi, L.R.; Pestana de Castro, A.F. (2003). Characterization of monkey enteropathogenic Escherichia coli (EPEC) and human typical and atypical EPEC serotype isolates from neotropical nonhumans primates. J. Clin. Microbiol., 41, 1225-1234.

7. Cobeljic, M.; Miljkovic-Selimovic, B.; Paunovic-Todosijevic, D.; Velickovic, Z.; Lepsanovic, Z.; Savic, D.; Ilic, R.; Kconstantinovic, S.; Jovanovic, B.; Kostic, V. (1996). Enteroaggregative Escherichia coli associated with an outbreak of diarrhoea in a neonatal nursery ward. Epidemiol. Infect., 117, 11-16.

8. Cravioto, A.; Gross, R.J.; Scotland, S.M.; Rowe, B. (1979). An adhesive factor found in strains of Escherichia coli belonging to the traditional infantile enteropathogenic serotypes. Curr. Microbiol., 3, 95-99.

9. Czeczulin, J.R.; Whittam, T.S.; Henderson, I.R.; Navarro-Garcia, F.; Navarro, J.P. (1979). Phylogenetic analysis of enteroaggregative and diffusely adherent Escherichia coli. Infect. Immun., 67, 2692-2699.

10. Elias, W.P.; Uber, A.P.; Tomita, S.K.; Trabulsi, L.R.; Gomes, T.A.T. (2002). Combinations of putative virulence markers in typical and variant enteroaggregative Escherichia coli strains from children with and without diarrhea. Epidemiol. Infect., 129, 49-55.

11. Eslava, C.; Navarro-Garcia, F.; Czeczulin, J.R.; Henderson, I.R.; Cravioto, A.; Nataro, J.P. (1998). Pet, an autotransporter enterotoxin from enteroaggregative Escherichia coli. Infect Immun., 66, 3155-3163.

12. Ewing, W.H. (1986). Genus Escherichia. In: Ewing, W.H. (Ed.), Edwards and Ewing's identification of Enterobacteriaceae, $4^{\text {th }}$ ed. Elsevier Science Publising Co., Inc., New York, N.Y., p.93-104.

13. Gomes, T.A.T.; Vieira, M.A.M.; Abe, C.M.; Rodrigues, D.; Griffin, P.; Ramos, S.R.T.S. (1998). Adherence patterns and adherence-related DNA sequences in Escherichia coli isolates from children with and without diarrhea in São Paulo City, Brazil. J. Clin. Microbiol., 36, 3609-3613.

14. Gomes, T.A.T.; Abe, C.M.; Vieira, M.A.M.; Falsetti, I.N. (1999). Uropathogenic Escherichia coli strains may carry potential virulence markers of enteroaggregative E. coli. In: Abstracts of the $99^{\text {th }}$ General Meeting of the American Society for Microbiology, Chicago, Ill., USA, p.250.

15. Guth, B.E.C.; Scaletsky, I.C.A. (1999). Virulence markers, adherence to HeLa cells and serogroups of Escherichia coli strains isolated from patients with cystitis and pyelonephritis in Brazil. Abstracts of the 99th General Meeting of the American Society for Microbiology, Chicago, Ill., USA, p.236.

16. Hammermueller, J.; Kruth, S.; Prescott, J.; Gyles, C. (1995). Detection of toxin genes in Escherichia coli isolated from normal dogs and dogs with diarrhea. Can. J. Vet. Res., 59, 265-270.

17. Hirsh, C.H.; Kirkham, C.; Wilson, D. (1993). Characteristics of Escherichia coli isolated from septic foals. Vet. Microbiol., 34, 123130.

18. Holland, R.E.; Sriranganathan, N.; DuPont, L. (1989). Isolation of enterotoxigenic Escherichia coli from a foal with diarrhea. J. Am. Vet. Med. Assoc., 194, 389-391.

19. Holland, R.E.; Schmidt, A.; Sriranganathan, N.; Grimes, S.D.; Wilson, R.A.; Brown, C.M.; Walker, R.D. (1996). Characterization of Escherichia coli isolated from foals. Vet. Microbiol., 48, 243-255.

20. Ike, K.; Kamada, M.; Anzai, T.; Imagawa, H.; Kumanomido, T.; Nakazawa, M.; Kashiwasaki, M.; Kume, T. (1987). Some properties of Escherichia coli isolated from foals with diarrhea and mares with metritis. Bull. Equine Res. Inst., 24, 33-41.

21. Itoh, Y.; Nagano, I.; Kunishima, M.; Ezaki, T. (1997). Laboratory investigation of enteroaggregative Escherichia coli $\mathrm{O}$ untypable:H10 associated with a massive outbreak of gastrointestinal illness. $J$. Clin. Microbiol., 35, 2546-2550. 
22. Kaper, J.B.; Nataro, J.P.; Mobley, H.L.T. (2004). Pathogenic Escherichia coli, Nat. Rev. Microbiol., 2, 123-140.

23. LeBlanc, M.M. (1991). Diseases of the reproductive system: the mare. In: Colahan, P.T., Mayhew, I.G.; Merrit, A.M.; More, J.N. (Ed.), Equine Medicine and Surgery, 4th ed. American Veterinary Publications, Goleta, pp.956-963.

24. Menard, L.P.; Dubreuil, J.D. (2002). Enteroaggregative Escherichia coli heat-stable enterotoxin 1 (EAST1): a new toxin with an old twist. Crit. Rev. Microbiol., 28, 43-60.

25. Milon, A.; Oswald, E.; De Rycke, J. (1999). Rabbit EPEC: a model for the study of enteropathogenic Escherichia coli. Vet. Res., 30, 203-219.

26. Nagy, B.; Fekete, P.Z. (1999). Enterotoxigenic Escherichia coli (ETEC) in farm animals. Vet. Res., 30, 259-284.

27. Nakazato, G.; Gyles, C.; Ziebell, K.; Keller, R.; Trabulsi, L.R.; Gomes, T.A.T.; Irino, K.; Silveira, W.D.; Pestana de Castro, A.F. (2004). Attaching and effacing Escherichia coli isolated from dogs in Brazil: characteristics and serotypic relationship to human enteropathogenic E. coli (EPEC). Vet. Microbiol., 101, 269-277.

28. Nataro, J.P.; Kaper, J.B. (1998). Diarrheagenic Escherichia coli. Clin. Microbiol. Rev., 11, 142-201.

29. Nataro, J.P.; Yikang, D.; Yingkang, D.; Walker, K. (1994). Aggr, a transcriptional activator of aggregative adherence fimbria I expression in enteroaggregative Escherichia coli. J. Bacteriol., 176, 4691-4699.

30. Penteado, A.S.; Aidar, L.; Pestana de Castro, A.F.; Yamada, A. Andrade, J.R.C.; Blanco, J.; Blanco, M.; Blanco, J.E. (2001). eae- negative attaching and effacing Escherichia coli from piglets with diarrhea. Res. Microbiol., 152, 75-81.

31. Racklyeft, D.J.; Love, D.N. ( 2000). Bacterial Infection of the lower respiratory tract in 34 horses. Aust. Vet. J., 78, 549-559.

32. Russo, T.A.; Johnson, J.R. (2000). Proposal for a new inclusive designation for extraintestinal pathogenic isolates of Escherichia coli: ExPEC. J. Infect. Dis., 181, 1753-1754.

33. Savarino, S.J.; Fasano, A.; Robertson, D.C.; Levine, M.M. (1991). Enteroaggregative Escherichia coli elaborate a heat-stable enterotoxin demonstrable in an in vitro rabbit intestinal model. J. Clin. Invest., $87,1450-145$

34. Sheikh, J.; Czeczulin. J.R.; Harrington, S.; Hicks, S.; Henderson, L.R.; Le Bouguénec, C.; Gounon, P.; Phillips, A.; Nataro, J.P. (2002). A novel dispersin protein in enteroaggregative Escherichia coli. J. Clin. Invest., 110, 1329-1337.

35. Uber, A.P.; Trabulsi, L.R.; Irino, K.; Beutin, L.; Ghilardi, A.C.; Gomes, T.A.; Liberatore, A.M.; de Castro, A.F.; Elias, W.P. (2006). Enteroaggregative Escherichia coli from humans and animals differ in major phenotypical traits and virulence genes. FEMS Microbiol. Lett., 256(2), 251-257.

36. Vieira, M.A.M.; Andrade, J.R.C.; Trabulsi, L.R.; Rosa, A.C.P.; Dias, A.M.C.; Ramos, S.R.T.S.; Frankel, G.; Gomes, T.A.T. (2001). Phenotypic and genotypic characteristics of Escherichia coli strains of non-enteropathogenic E. coli (EPEC) serogroups that carry eae and lack the EPEC adherence factor and Shiga toxin DNA probe sequences. J. Infect. Dis., 183, 762-772. 